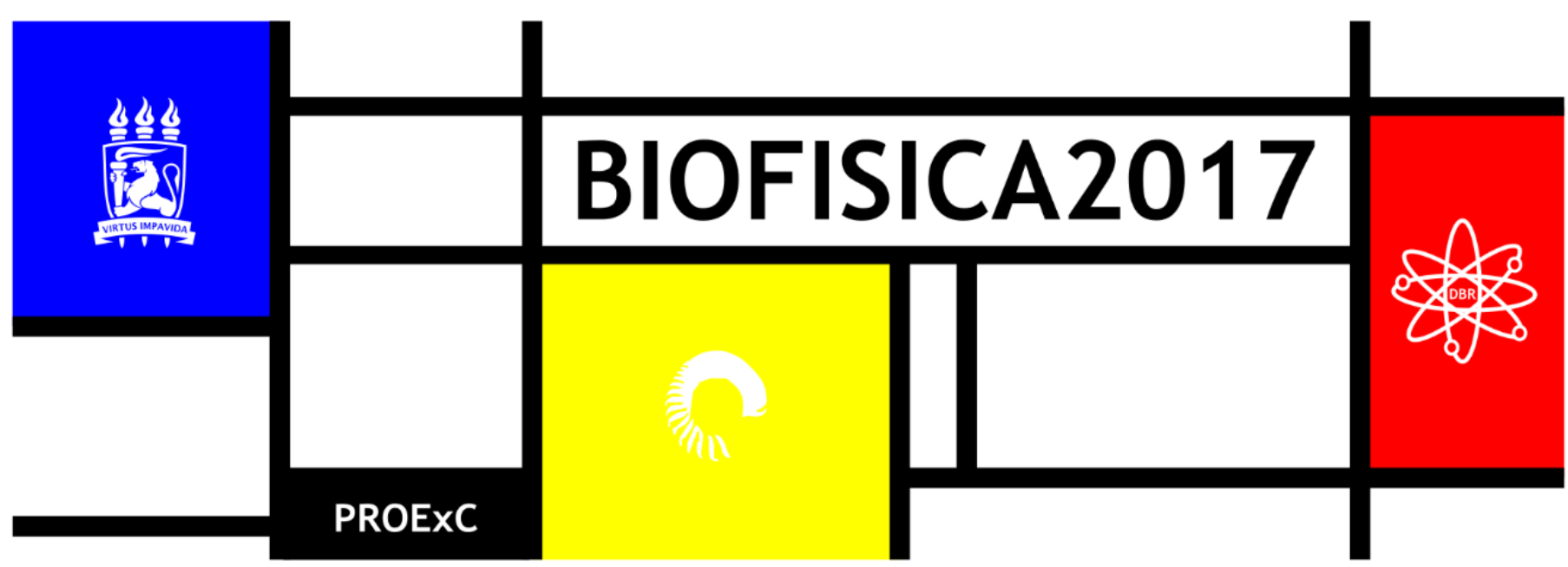

\title{
ANÁLISE TOXICOLÓGICA DA ÁGUA DO RIO CAPIBARIBE DA CIDADE DE TORITAMA-PE
}

\author{
${ }^{1}$ Departamento de Biofísica e Radiobiologia, UFPE - PE \\ *viniciushtmorais@hotmail.com
}

Vinícius Morais ${ }^{1}$, Ricardo Filho ${ }^{1}$, Williams Siqueira ${ }^{1}$, Maria Marinho ${ }^{1}$, Ana Melo ${ }^{1}$

\begin{abstract}
INTRODUÇÃO
A intensa liberação de substâncias químicas no meio ambiente tem causado inúmeros problemas aos seres vivos. Sabe-se que os primeiros organismos afetados por essas substâncias estão presentes nos ecossistemas aquáticos, pois estes são utilizados como um dos principais locais de despejo de diferentes tipos de dejetos e resíduos produzidos pelo homem (ANDRADE et al., 2013). A exposição dos ecossistemas à poluição pode trazer consequências para sua sustentabilidade e conservação da biodiversidade, pois alguns poluentes químicos podem atingir o material genético dos organismos e causar mutações (TALLARICO et al., 2004).

A indústria têxtil desempenha um importante papel na economia nacional e mundial. Entretanto, do ponto de vista ambiental, suas atividades são consideradas potencialmente poluidoras $e$ utilizadoras de recursos naturais (PINHEIRO, 2011). O setor têxtil de Pernambuco é considerado um dos polos economicamente mais importante no estado. A concentração das empresas do setor de confecções encontra-se nos municípios de Caruaru, Santa Cruz do Capibaribe, Surubim e Toritama (SANTOS 2012).

Os efeitos das substancias químicas podem ser observados por meio da toxicidade, que pode ser classificada em: aguda, subcrônica e crônica. A toxicidade aguda é aquela em que os efeitos tóxicos em animais são produzidos por uma única ou por múltiplas exposições a uma substância, por qualquer via, por curto período de tempo. A toxicidade subcrônica é aquela em que os efeitos tóxicos em animais produzidos por exposições diárias repetidas a uma substância, por qualquer via, aparecem em um período de aproximadamente $10 \%$ do tempo de vida de exposição do animal ou alguns meses. A crônica é aquela em que os efeitos tóxicos ocorrem após repetidas exposições, por um período longo de tempo, geralmente durante toda a vida do animal ou aproximadamente $80 \%$ do tempo de vida (RAND et al.,1995).
\end{abstract}

\section{MATERIAIS E MÉTODOS}

O objetivo deste trabalho foi avaliar a toxicidade da água do rio Capibaribe da região têxtil do município de Toritama-PE por meio do ensaio com Biomphalaria glabrata. Foi coletada água do rio Capibaribe-PE na montante do rio na cidade de Toritama-PE para realização do bioensaio. As amostras de água coletadas foram armazenadas em recipientes com marcações contendo a data, hora e as condições meteorológicas do dia e em seguida enviadas ao Laboratório de Radiobiologia do Departamento de Biofísica e Radiobiologia da Universidade Federal de Pernambuco em caixas térmicas com gelo para manter a temperatura baixa, evitando possíveis contaminações. Foram utilizados para o experimento os animais adultos da espécie Biomphalaria glabrata pigmentados. Estes animais foram mantidos no moluscário do Laboratório de Radiobiologia do Departamento de Biofísica e Radiobiologia da UFPE, em aquários com capacidade para $20 \mathrm{~L}$ de água, $\mathrm{pH} \approx 7,0 \mathrm{e}$ temperatura de $25 \pm 2{ }^{\circ} \mathrm{C}$. A alimentação dos moluscos foi realizada diariamente com alface fresca orgânica (Lactura sativa) e a troca da água ocorreu uma vez por semana, com recolhimento das respectivas desovas.

Para o teste com a água do rio, moluscos adultos, B. glabrata, foram separados individualmente em recipientes com capacidade para $180 \mathrm{~mL}$ de água para cada caramujo. Esta pré-seleção foi realizada para a verificação da maturidade sexual dos mesmos. Utilizou-se para a verificação 40 moluscos com diâmetro de concha entre 12 a $14 \mathrm{~mm}$. Em seguida, 30 moluscos sexualmente maduros foram separados para serem utilizados no experimento.

Foi realizado teste de toxicidade aguda com os moluscos adultos, sexualmente maduros, expostos à água do rio Capibaribe num intervalo de $48 \mathrm{~h}$ de exposição. Os animas utilizados nos experimentos foram separados em grupo controle negativo (água filtrada e declorada) e grupo exposto à água do rio Capibaribe, em um total de 15 animais por grupo, consistindo de cinco animais por recipiente, sendo o experimento realizado em triplicata. Passado o tempo de exposição foi realizada a confecção das lâminas para posterior análise morfológica dos hemócitos.

Para cada molusco exposto a água do rio Capibaribe, foi coletado $100 \mu \mathrm{L}$ de hemolinfa e colocado em lâminas microscópicas, em seguida foi depositado sobre à amostra a mesma quantidade de ácido etilenodiaminotetracético (EDTA) e Ringer na concentração final de $10 \mathrm{mM}$. Em seguida, cada lâmina foi colocada por 40 minutos em câmara úmida. Passado este tempo, as células foram fixadas com $200 \mu \mathrm{L}$ gluteraldeído a $1 \%$ em solução de Ringer, por 10 minutos. Em seguida enxaguadas com Ringer e coradas. Para corar as lâminas, foi utilizada uma solução estoque de Giemsa (Merck), Azur-eosina-azul de metileno, diluída em tampão fosfato 
(pH 6,8, a 5\%). As lâminas foram submersas nesta solução por 10 minutos e em seguida lavadas com água destilada e posteriormente submetidas à secagem em temperatura ambiente. Posteriormente, as lâminas foram analisadas com auxilio de um microscópio óptico (Centauro).

\section{RESULTADOS E DISCUSSÃO}

Durante a análise das lâminas foram observadas diferentes alterações morfológicas nos hemócitos dos moluscos submetidos à amostra da água do rio Capibaribe. As modificações analisadas foram micronúcleos, binucleações e apoptoses (FIGURA 1).

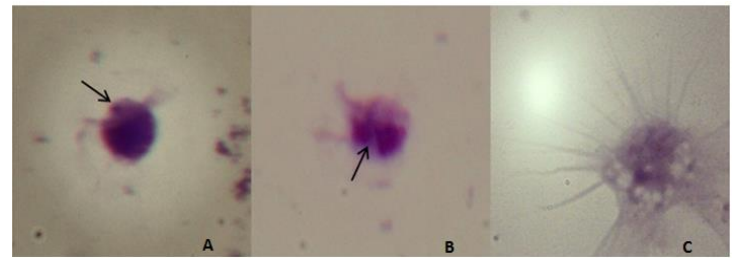

Figura 1. A) micronúcleo; B) binucleação; C) apoptose. Fonte: Lima, M. V

Micronúcleos consistem em pequenas quantidades de DNA que surgem no citoplasma quando fragmentos de cromossomos ou cromátides ou cromossomos inteiros não são incorporados dentro do núcleo da célula filha durante a mitose, frequentemente, porque estes fragmentos não possuem um centrômero. Os fragmentos de DNA deixados para trás são incorporados dentro de núcleos secundários, que por serem muito menores que o núcleo principal da célula, recebem o nome de micronúcleos (HEDDLE et al., 1983).

De acordo com Fenech (2000) as formações de células binucleadas provavelmente são originarias quando os centrômeros de cromossomos dicêntricos são distendido para pólos opostos durante a anáfase. Neste caso, o DNA resultante da ponte é recoberto pelo envoltório nuclear.

Apoptose é um fenômeno de morte celular programada, reconhecida morfologicamente como um fenômeno distinto de morte há mais de 30 anos por Kerr et al. (1972).

0 padrão de alterações morfológicas e bioquímicas celulares que estão associadas com a morte programada celular e em certos processos patológicos, in vivo, inclui o aparecimento de vacúolos citoplasmáticos, encolhimento celular, diminuição do contato com as células vizinhas, fragmentação da membrana do núcleo e condensação da cromatina. Portanto, a apoptose celular ocorre em defesa de danos celulares que já não são mais reparáveis pelo organismo.

Os hemócitos de B. glabrata expostos à água do rio Capibaribe foram analisados morfologicamente e quantitativamente.

Tabela 1. Número total de hemócitos originários do $B$. glabrata expostos a água do rio Capibaribe sem diluições.

\begin{tabular}{ccccc}
\hline Grupos & $\begin{array}{c}\mathrm{N}^{\circ} \text { Total de } \\
\text { Hemócitos }\end{array}$ & $\begin{array}{c}\text { Micronúcleo } \\
(\mathrm{MN})\end{array}$ & Apoptose & Binucleação \\
\hline $\begin{array}{c}\text { Amostra } \\
\text { Bruta } \\
(100 \%)\end{array}$ & 1000 & 10 & 52 & 15 \\
Controle & 1000 & - & - & 2 \\
\hline
\end{tabular}

Foi realizada uma avaliação de 1000 hemócitos dos grupos apresentados (TABELA 1), em que as células pertencentes ao grupo controle não apresentaram alterações referentes à micronúcleos e apoptoses celulares, tendo sido observado 2 células binucleadas. Em contrapartida, o grupo exposto à água do rio Capibaribe apresentou 15 binucleações, 10 micronúcleos e 52 apoptoses celulares, demonstrando assim danos celulares potencialmente genotóxicos.

\section{CONCLUSÕES}

0 teste agudo do Biomphalaria glabrata adulto demonstrou que o animal sofreu danos decorrentes da toxicidade da água do rio. Os moluscos submetidos a exposição aguda apresentaram maior número de hemócitos com apoptose celular, micronúcleos e binucleações quando comparados ao grupo controle. Este resultado foi um indicativo de elevada toxicidade da água presente no Rio Capibaribe situado na região têxtil de Toritama-PE.

Os resultados demonstraram que os hemócitos de $B$. glabrata são sensíveis a presença de agentes químicos, e que portanto, podem ser utilizados como biomarcadores dos efeitos oriundos dos poluentes presentes em meios aquáticos.

\section{REFERÊNCIAS}

Andrade Jr, G., Aride, P. H., Honda, R. T., Ferreira, M., Nozawa, S. R., Santos, S., \& Lima, J. P. Ajustes hematológicos em tambaqui (colossoma macropomum curvier, 1818) exposto a diferentes concentrações de chorume. Revista Colombiana de Ciência Animal, v.5, n.1, p.71-82, 2013.

FENECH, Michael. The in vitro micronucleus technique. Mutation Research/Fundamental and Molecular Mechanisms of Mutagenesis, v. 455 , n. 1 , p. $81-95,2000$.

HEDDLE, John A. et al. The induction of micronuclei as a measure of genotoxicity: A report of the US Environmental Protection Agency Gene-Tox Program. Mutation Research/Reviews in Genetic Toxicology, v. 123, n. 1, p. 61-118, 1983.

KERR, John FR; WYLLIE, Andrew H.; CURRIE, Alastair R. Apoptosis: a basic biological phenomenon with wide-ranging implications in tissue kinetics. British journal of cancer, v. 26, n. 4, p. 239, 1972.

Pinheiro, A. S. Avaliação da toxicidade e genotoxicidade dos corantes azo reativos Remazol Preto $B$ e Remazol Alaranjado R3 e da eficácia da radiação com feixe de elétrons na redução da cor $e$ efeito tóxicos. 2011. 139f.. Tese de Doutorado em Tecnologia Nuclear - Instituto de Pesquisas Energéticas e Nucleares, Universidade de São Paulo, São Paulo.

Rand, G. M. Fundamentals of aquatic toxicology: effects, environmental fate and risk assessment. $1^{\circ}$. Ed. CRC Press. Washington, 1995.

Santos, J. J. D. Avaliação do Arranjo Produtivo Local de Confecção no Município de Riacho das Almas no Estado de Pernambuco. 2012. 91f.. Dissertação de mestrado - Centro de Ciências Sociais, Universidade Federal de Pernambuco, Recife.

Tallarico, L. F., Okazaki, K., Kawano, T., De Bragança Pereira, C. A. Dominant lethal effect of $60 \mathrm{Co}$ gamma radiation in Biomphalaria glabrata (SAY, 1818). Mutation Research, v.5, n.61, p.139-145, 2004. 